Gut, 1974, 15, 903-906

\title{
Thoracic duct and hepatic lymph in idiopathic portal hypertension
}

\author{
A. K. S. SAMANTA, V. K. SAINI, P. N. CHHUTtANi, B. S. PATRA, S. VAShista, \\ AND D. V. DATTA \\ From the Division of Hepatic Diseases, Postgraduate Institute of Medical Education and Research, \\ Chandigarh, India
}

SUMMARY Lymph dynamics in idiopathic portal hypertension has been studied in two phases. In the first phase thoracic duct lymph transport was studied in 11 patients with idiopathic portal hypertension by cannulating the duct. This revealed altered lymph transport in the form of a distended thoracic duct, raised pressure in the duct, and haemorrhagic lymph with an increased flow rate. The lymph flow rate was analysed in relation to various hepatic haemodynamic and biochemical parameters. In the second phase of the study hepatic lymphatics were studied by percutaneous hepatography in 16 patients with idiopathic portal hypertension. By this technique hepatic lymphatics were opacified in patients with idiopathic portal hypertension and cirrhosis with equal frequency. The significance of this finding in relation to the altered hepatic haemodynamics and thoracic duct lymph transport is discussed.

Studies in patients with cirrhosis have demonstrated greatly distended thoracic duct and haemorrhagic lymph with a flow rate increased three to six times and a significantly raised thoracic duct pressure (Dumont and Mulholland, 1960; Samanta, 1969; Datta, Samanta, Patra, Saini, and Chhuttani, 1971). This has been attributed to the increased lymph formation in the liver in cirrhosis of the liver (Baggenstoss and Cain, 1957; Dumont and Mulholland, 1960; Aiello, Enquist, Ikezono, and Levowitz, 1960). It must be emphasized that the haemodynamics and gross structural changes seen in cirrhosis of the liver have been incriminated as the important factors in the genesis of increased lymph in the liver. A sizeable percentage of cases of intrahepatic portal hypertension are now being recognized where the hepatic architectural changes lack the classical features of cirrhosis, and clinically as well as biochemically liver function is fairly well preserved (Sherlock, 1967; Basu, Boyer, Bhattacharya, Basu Mallik, and Sen Gupta, 1967; Basu Mallik, Sen Gupta, Basu, Biswas, Pal, and Boyer, 1967). Haemodynamically the portal hypertension

Correspondence to: Dr A. K. S. Samanta, Division of Hepatic Disease, Postgraduate Institute of Medical Education and Research, Chandigarh, India

Received for publication 23 July 1974. in these patients is predominantly of the presinusoidal type with normal or increased estimated hepatic blood flow with only mild to moderate elevation of the hepatic vascular resistance (Datta, 1969). These patients thus provide an opportunity to evaluate the relative role of the hepatic haemodynamic and structural changes in the genesis of altered thoracic duct and hepatic lymph transport. The present study was therefore undertaken to study these problems by thoracic duct cannulation and percutaneous hepatography in patients with idiopathic portal hypertension in the hope that they might delineate the relative role of hepatic haemodynamic and structural changes in the genesis of altered lymph transport.

\section{Material and Methods}

The diagnosis of idiopathic portal hypertension (Sherlock, 1967; Basu et al, 1967; Basu Mallik et al, 1967) was made from the overall correlation of the clinical, biochemical, haemodynamic, radiological, and hepatic histological findings. The haemodynamic study (Caeser, Shaldon, Chiandussi, Guevara, and Sherlock, 1961) comprised the estimation of the intrasplenic pressure (ISP), free hepatic venous pressure (FHVP), wedge hepatic venous pressure (WHVP), corrected sinusoidal pressure 
(CSP), estimated hepatic blood flow (EHBF), and hepatic vascular resistance (HVR).

The lymph dynamics was studied in two phases. In the first the thoracic duct lymph was studied to see whether there is any alteration in lymph transport in these patients. In the second the hepatic lymphatics were studied by the technique of percutaneous hepatography (Clain and McNulty, 1968) in 16 patients with idiopathic portal hypertension. In addition, the hepatic lymph was studied in 13 other cases of cirrhosis of the liver and five control subjects.

The thoracic duct was cannulated and the lymph drained for a variable period of 21 to 32 hours by the method of Dumont and Mulholland (1960) in 11 patients with idiopathic portal hypertension, in 10 with postnecrotic cirrhosis, and in two who had no liver disease but were undergoing scalene node biopsy. Patients with idiopathic portal hypertension and cirrhosis had bleeding from varices in the recent past. Lymph was replaced volume for volume by intravenous infusions of glucose saline. The parameters used for the study of thoracic duct lymph were the assessment of thoracic duct size and pressure, lymph flow rate, haematocrit, and protein. Thoracic duct pressure was measured by the method of Dumont and Mulholland (1960).

\section{Results (Tables I and II)}

In contrast to the findings in subjects without any liver disease the thoracic duct was appreciably greater in diameter, distended, and turgid with lymph in patients with idiopathic portal hypertension and this gross appearance was comparable to that seen in cirrhosis.

The lymph flow rate was $(2 \cdot 70 \pm 1.68 \mathrm{ml} / \mathrm{min})$ consistently higher in these patients than the normal of $1 \mathrm{ml} /$ minute. Patients with cirrhosis of the liver had a mean lymph flow rate of $3.44 \pm 1.28 \mathrm{ml} /$ minute. The difference between the two groups was not significant $(P>0 \cdot 20)$. It is interesting to note that the mean lymph flow rate in three patients with idiopathic portal hypertension with ascites was higher $(3.0 \pm 1.73 \mathrm{ml} / \mathrm{min})$ than that in eight nonascitic patients $(2.59 \pm 1.76 \mathrm{ml} / \mathrm{min})$. However, the difference was statistically not significant (P > 0.05).

Analysis of the lymph flow rate in relation to certain biochemical parameters of hepatocellular dysfunction did not reveal any statistically significant correlation with the serum albumin $(r+0.098)$ and the 45-minute plasma bromsulphthalein retention $(r+0.022)$ although there was a positive correlation with certain haemodynamic parameters such as FHVP $(r+0 \cdot 24)$, WHVP $(r+0 \cdot 125)$,

\begin{tabular}{|c|c|c|c|c|}
\hline $\begin{array}{l}\text { Patient } \\
\text { No. }\end{array}$ & $\begin{array}{l}\text { Mean Lymph } \\
\text { Flow Rate } \\
\text { (ml/min) }\end{array}$ & $\begin{array}{l}\text { Lymph } \\
\text { Haemato- } \\
\text { crit }(\%)\end{array}$ & $\begin{array}{l}\text { Lymph/ } \\
\text { Serum } \\
\text { Total } \\
\text { Protein } \\
\text { Ratio } \\
(\mathrm{g} / 100 \mathrm{ml})\end{array}$ & $\begin{array}{l}\text { Thoracic Duct } \\
\text { Pressure } \\
\text { (mm of saline) }\end{array}$ \\
\hline $\begin{array}{r}1 \\
2 \\
3 \\
4 \\
5 \\
6 \\
7 \\
8 \\
9 \\
10 \\
11\end{array}$ & $\begin{array}{l}2 \cdot 0 \\
5 \cdot 0 \\
6 \cdot 8 \\
1 \cdot 8 \\
1 \cdot 9 \\
2 \cdot 4 \\
1 \cdot 6 \\
2 \cdot 7 \\
2 \cdot 3 \\
2 \cdot 0 \\
1 \cdot 2\end{array}$ & $\begin{array}{l}1.0 \\
2.0 \\
2.0 \\
1.0 \\
1.0 \\
1.0 \\
1.0 \\
2.0 \\
1.0 \\
2.0 \\
2.0\end{array}$ & $\begin{array}{r}1 \cdot 4 / 5 \cdot 0 \\
2 \cdot 7 / 6 \cdot 8 \\
0 \cdot 7 / 6 \cdot 6 \\
1 \cdot 8 / 6 \cdot 3 \\
/ 6 \cdot 3 \\
1 \cdot 2 / 6 \cdot 1 \\
0 \cdot 9 / 5 \cdot 5 \\
1 \cdot 7 / 5 \cdot 3 \\
3 \cdot 6 / 6 \cdot 1 \\
1 \cdot 1 / 4 \cdot 9 \\
1 \cdot 6 / 4 \cdot 1\end{array}$ & $\begin{array}{r}40 \\
150 \\
360 \\
400 \\
530 \\
390 \\
860 \\
220 \\
360 \\
400 \\
60\end{array}$ \\
\hline \multicolumn{5}{|c|}{$\begin{array}{l}\text { Idiopathic } \\
\text { portal } \\
\text { hypertension } \\
\text { (mean } \pm\end{array}$} \\
\hline SD) & $2 \cdot 70 \pm 1.68$ & $1.45 \pm 0.53$ & $0.29 \pm 0.14$ & $342 \cdot 72 \pm 230 \cdot 71$ \\
\hline (10 cases) & $3.44 \pm 1.28$ & $1.60 \pm 0.75$ & $0.41 \pm 0.20$ & $310.70 \pm 179.08$ \\
\hline \multicolumn{2}{|c|}{ Control under $1 \mathrm{ml} / \mathrm{min}$} & No RBC. & $0.73 \pm 0.11$ & Under 116 \\
\hline
\end{tabular}

Table I Thoracic duct lymph transport in idiopathic portal hypertension

\begin{tabular}{|c|c|c|c|c|}
\hline \multirow[t]{2}{*}{ Diagnosis } & \multirow{2}{*}{$\begin{array}{l}\text { Number of } \\
\text { Cases }\end{array}$} & \multicolumn{2}{|c|}{ Hepatic Vein } & \multirow{2}{*}{$\begin{array}{l}\text { Lymphatics } \\
\text { Seen } \\
\text { (number of } \\
\text { cases) }\end{array}$} \\
\hline & & $\begin{array}{l}\text { Size } \\
(\mathrm{cm}) \\
\text { Mean } \pm S D\end{array}$ & $\begin{array}{l}\text { Transit Time } \\
(\text { sec) } \\
\text { Mean } \pm S D\end{array}$ & \\
\hline $\begin{array}{l}\text { Idiopathic } \\
\text { portal } \\
\text { hypertension }\end{array}$ & 16 & $\begin{array}{l}0.41 \\
\pm 0.09\end{array}$ & $\begin{array}{l}3.67 \\
\pm 0.5\end{array}$ & 3 \\
\hline Cirrhosis & 13 & $\begin{array}{l}1.09^{1} \\
\pm 0.46\end{array}$ & $\begin{array}{l}\text { More than } \\
5\end{array}$ & 2 \\
\hline Control & 5 & $\begin{array}{l}0.36 \\
\pm 0.13\end{array}$ & $\begin{array}{l}4 \cdot 0 \\
\pm 2 \cdot 0\end{array}$ & Nil \\
\hline
\end{tabular}

Table II Percutaneous hepatographic findings in idiopathic portal hypertension

${ }^{1} \mathrm{P}<0.05$

EHBF $(r+0.56)$, and HVR $(r+0.053)$. The values, however, were statistically not significant. The mean thoracic duct pressure in idiopathic portal hypertension was $342.72 \pm 230.7 \mathrm{~mm}$ of saline. This compares well with that recorded in cirrhosis of the liver (310.70 $\pm 179.08 \mathrm{~mm}$ of saline) and is remarkably higher than normal. There was no correlation between the portal pressure and the thoracic duct pressure.

The lymph/serum protein ratio, which gives indirect evidence of the predominant source of lymph in the thoracic duct (Witte, Dumont, Cole, Witte, and Kinter, 1969), showed great variation both in idiopathic portal hypertension $(0.11$ to 0.59$)$ and in cirrhosis of the liver $(0.22$ to 0.90$)$. However, the mean lymph/serum protein ratio was markedly lower in idiopathic portal hypertension $(0 \cdot 29 \pm 0 \cdot 14)$ 
than that in cirrhosis of the liver $(0.41 \pm 0.20)$ but the difference did not reach the level of statistical significance ( $P>0.05)$.

Lymph was grossly haemorrhagic in all patients with idiopathic portal hypertension and the lymph haematocrit was $1.45 \pm 0.53 \%$.This is comparable with the finding in patients with cirrhosis $(1.6 \pm$ $0.25 \%$ ).

Hepatic lymphatics were demonstrated in three out of the 16 patients studied by the technique of percutaneous hepatography. This was comparable with the observation in cirrhosis where the lymphatics were visualized in two out of the 13 cases whereas in none of the five control subjects could the hepatic lymphatics be visualized (table II). These lymphatics appear as tortuous and beaded interlacing channels traversing the liver towards its hilum and finally draining to the paraaortic region. Hepatic vein size, measured at identical points from the midline, did not show any appreciable difference between patients with idiopathic portal hypertension $(0.41 \pm 0.09 \mathrm{~cm})$ and controls $(0.36 \pm 0.13 \mathrm{~cm})$. In cirrhotics the hepatic vein was significantly bigger in size $(1.09 \times 0.46 \mathrm{~cm})$ as compared with that in patients with idiopathic portal hypertension $(\mathrm{P}<$ $0.01)$ and controls $(P<0.01)$. The transit time of the hepatic veins, measured as the time taken by the contrast to clear a radicle of a hepatic vein, was within normal limits $(4.0 \pm 2.0 \mathrm{sec})$ in idiopathic portal hypertension $(3.67 \pm 0.5 \mathrm{sec})$ but was prolonged in cirrhotics (more than $5 \mathrm{sec}$ ).

\section{Discussion}

The present study has shown the interesting finding of a greatly distended thoracic duct with haemorrhagic lymph and an increased thoracic duct lymph flow rate and pressure. The increased thoracic duct lymph could originate either in the liver sinusoids or the extrahepatic splanchnic vascular bed. In this context it is important to note the finding of percutaneous hepatography which demonstrated the tortuous and prominent hepatic lymphatics in idiopathic portal hypertension and cirrhosis of the liver with almost equal frequency.

Increased liver lymph production can occur either due to elevation in the sinusoidal pressure or to increased sinusoidal permeability (Zeppa and Womack, 1963; Dumont and Mulholland, 1965). In cirrhosis it is generally ascribed to the increased hydrostatic pressure (Dumont and Mulholland, 1965). However, the cause is not known in idiopathic portal hypertension where change in postsinusoidal resistance is not a marked feature. From the present study no single haemodynamic parameter can be solely incriminated in the pathogenesis of increased liver lymph formation in this clinical syndrome. This is evident from the fact that there was no statistically significant correlation between the lymph flow rate and intrasplenic pressure, wedge hepatic venous pressure, free hepatic venous pressure, and corrected sinusoidal pressure. However, their contribution may be variable.

From the available knowledge on the pathophysiology of idiopathic portal hypertension the finding of haemorrhagic lymph can be an additional pointer towards the hepatic sinusoidal bed as one of the sources of increased thoracic duct lymph. That liver is probably not the only source of this lymph is also evident from the finding of the thoracic duct lymph/serum protein ratio. By simultaneous measurement of the protein content in the liver, and in the intestinal and thoracic duct lymph in controls, cirrhotics, and cirrhotics with extrahepatic obstruction, Witte et al (1969) showed that thoracic duct lymph protein content approximates to plasma protein when liver is the only source of lymph, and its protein content will be lowered by the extent of the dilution by intestinal lymph which is low in protein content. In normal subjects the thoracic duct lymph protein concentration was $73 \pm 11 \%$ of plasma proteins as liver lymph is invariably diluted with some intestinal lymph. They also showed that the liver was the major source of thoracic duct lymph which was high in protein content in uncomplicated cirrhosis with a definite but variable contribution from the intestinal lymphatics. In cases in which extrahepatic obstruction occurs the intestinal lymph contribution increases and may be the predominant source of thoracic duct lymph. This then leads to dilution of the liver lymph protein resulting in low thoracic duct lymph protein. In the present study the lymph/ serum protein ratio in idiopathic portal hypertension $(0.29 \pm 0.14)$ was distinctly lower than in cirrhosis of the liver $(0.41 \pm 0.20)$. This may mean that the contribution of intestinal lymph to the thoracic duct in idiopathic portal hypertension is a more important factor than that in cirrhosis.

Finding elevated thoracic duct pressures in these patients was rather unexpected. A similar elevation of thoracic duct pressure has been reported in cirrhosis (Dumont and Mulholland, 1960; Samana, 1969; Datta et al, 1971) but there is no unanimity of opinion that this corresponds to the elevated portal pressure (Bowers, McKinnon, Marino, and Culverwell, 1964; Kessler, Santoni, Tice, and Zimmon, 1969). The raised thoracic duct pressure in idiopathic portal hypertension could not be correlated either with the intrasplenic or with any other haemodynamic parameters. The mechanism and significance of this finding is not clearly under- 
stood. This might reflect a phenomenon of fluid overload of the lymphatic.

\section{References}

Aiello, R. G., Enquist, I. F., Ikezono, E., and Levowitz, B. S. (1960). An experimental study of the role of hepatic lymph in the production of ascites. Surg. Gynec. Obstet., 111, 77-81.

Baggenstoss, A. H., and Cain, J. C. (1957). The hepatic hilar lymphatics of man and their relation to ascites. New Engl. J. Med., 256, 531-535.

Basu, A. K., Boyer, J., Bhattacharya, R., Basu Mallik, K. C., and Sen Gupta, K. P. (1967). Non-cirrhotic portal fibrosis with portal hypertension: a new syndrome. I. Clinical and function studies and results of operations. Indian J. med. Res., 55, 336-350.

Basu Mallik, K. C., Sen Gupta, K. P., Basu, A. K., Biswas, S. K., Pal, N. C., and Boyer, J. (1967). Non-cirrhotic portal fibrosis with portal hypertension: a new syndrome. II. Histopathological studies. Ind. J. med. Res., 55, 351-359.

Bowers, W. F., McKinnon, W. M. P., Marino, J. M., and Culverwell, J. T. (1964). Cannulation of the thoracic duct, its role in the, pre-shunt management of haemorrhage due to oesophageal varices. Report of a case. J. Int Coll. Surg., 42, 71-76.

Caeser, J., Shaldon, S., Chiandussi, L., Guevara, L., and Sherlock, S. (1961). The use of indocyanin green in the measurement of hepatic blood flow and as a test of hepatic function. Clin. Sci., 21, 43-57.
Clain, D., and McNulty, J. (1968). A radiological study of lymphatics of the liver. Brit. J. Radiol., 41, 662-668.

Datta, D. V. (1969). In Monogram on Non-Cirrhotic Portal Fibrosis. Indian Council of Medical Research, New Delhi.

Datta, D. V., Samanta, A. K. S., Patra, B. S., Saini V. K., and Chhuttani, P. N. (1971). Management of bleeding oesophageal varices by draining lymph from the thoracic dust. Gut, 12 48-50.

Dumont, A. E., and Mulholland, J. H. (1960). Flow rate and composition of thoracic-duct lymph in patients with cirrhosis. New Engl. J. Med., 263, 471-474.

Dumont, A. E., and Mulholland, J. H. (1965). Hepatic lymph in cirrhosis. In Progress in Liver Disease, Vol. 2, edited by F. F. Schaffiner, pp. 427-441. Grune and Stratton, New York.

Kessler, R. E., Santoni, E., Tice, D. A., and Zimmon, D. S. (1969) Effect of lymph drainage on portal pressure and bleeding oesophageal varices. Gastroenterology, 56, 538-547.

Samanta, A. K. S. (1969). Effects of thoracic duct lymph drainage on portal hypertension in man. A thesis submitted to the Postgraduate Institute of Medical Education and Research, Chandigarh for Doctor of Medicine.

Sherlock, S. (1967). Non cirrhotic intrahepatic portal hypertension. Extrait de la Revue International de Hepatologic Tom XII. No $S:$ 713-718.

Witte, M. H., Dumont, A. E., Cole, W. R., Witte, C. L., and Kinter, K. (1969). Lymph circulation in hepatic cirrhosis: effect of portacaval shunt. Ann. intern. Med. 70, 303-310.

Zeppa, R., and Womack, N. A. (1963). Humoral control of hepatic lymph flow. Surgery, 54, 37-44.

\section{The October 1974 Issue}

\section{THE OCTOBER 1974 ISSUE CONTAINS THE FOLLOWING PAPERS}

Mucous change in the human duodenum: A light and electron microscopic study and correlation with disease and gastric acid secretion w. J. A. PATRICK, D. DENHAM, AND A. P. M. FORREST

Enzyme histochemical study of fat absorption in human duodenal mucosa H. MONGES, A. CHAMLIAN, A. COUGARD, AND B. MATHIEU

An investigation into the enzyme histochemistry of adenocarcinomas of human large intestine and of the transitional epithelium immediately adjacent to them J. R. MARSDEN AND I. M. P. DAWSON

The relief of bone pain in primary biliary cirrhosis with calcium infusions A. B. AJDUKIEWICZ, J. E. AGNEW, P. D. BYERS, M. R. WILLS, AND SHEILA SHERLOCK

Haemolysis in experimental cholestasis: Possible role of erythrocyte sialic acid LAWRIE W. POWELL, J. THOMAS LAMONT, AND KURT J. ISSELBACHER
A comparison of the accuracy of peritoneoscopy and liver biopsy in the diagnosis of cirrhosis $M$. BRUGUERA, J. M. BORDAS, P. MAS, AND J. RODES

The relationship and epidemiology of acute terminal ileitis and Crohn's disease J. KEWENTER, L. HULTÉN, AND N. G. KOCK

Enzyme changes in human small bowel mucosa during culture in vitro J. D. MITCHELL, JUDITH MITCHELL, AND T. J. PETERS

\section{Technique}

A modification to the method of George for studying gastric emptying J. N. HUNT

Progress report Alpha-fetoprotein in primary liver cancer and other diseases MICHAEL KEW

\section{The British Society of Gastroenterology}

British Society for Digestive Endoscopy

Notes and activities

Copies are still available and may be obtained from the PUBLISHING MANAGER,

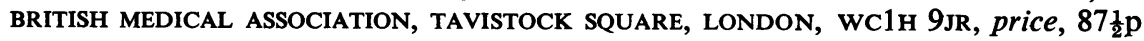

